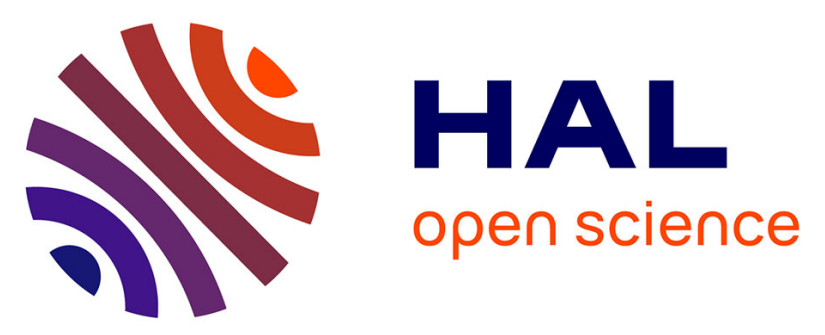

\title{
Modelling transpiration of greenhouse gerbera (Gerbera jamesonii H. Bolus) grown in substrate with saline water in a Mediterranean climate
}

Giulia Carmassi, Laura Bacci, Matteo Bronzini, Luca Incrocci, Rita Maggini, Gianni G. Bellocchi, Daniele Massa, Alberto Pardossi

\section{To cite this version:}

Giulia Carmassi, Laura Bacci, Matteo Bronzini, Luca Incrocci, Rita Maggini, et al.. Modelling transpiration of greenhouse gerbera (Gerbera jamesonii H. Bolus) grown in substrate with saline water in a Mediterranean climate. Scientia Horticulturae, 2013, 156, pp.9-18. 10.1016/j.scienta.2013.03.023 . hal-02650961

\section{HAL Id: hal-02650961 https://hal.inrae.fr/hal-02650961}

Submitted on 29 May 2020

HAL is a multi-disciplinary open access archive for the deposit and dissemination of scientific research documents, whether they are published or not. The documents may come from teaching and research institutions in France or abroad, or from public or private research centers.
L'archive ouverte pluridisciplinaire HAL, est destinée au dépôt et à la diffusion de documents scientifiques de niveau recherche, publiés ou non, émanant des établissements d'enseignement et de recherche français ou étrangers, des laboratoires publics ou privés. 


\title{
Modelling transpiration of greenhouse gerbera (Gerbera jamesonii $\mathrm{H}$. Bolus) grown in substrate with saline water in a Mediterranean climate
}

\author{
Giulia Carmassi ${ }^{a}$, Laura Bacci ${ }^{b}$, Matteo Bronzini $^{a}$, Luca Incrocci ${ }^{a}$, Rita Maggini ${ }^{a}$, \\ Gianni Bellocchi ${ }^{\mathrm{c}}$, Daniele Massa ${ }^{\mathrm{d}}$, Alberto Pardossi ${ }^{\mathrm{a}, *}$ \\ a Department of Agriculture, Food and Environment, University of Pisa, Pisa, Italy \\ ${ }^{\mathrm{b}}$ Institute of Biometeorology, CNR-IBIMET, Sesto Fiorentino, Firenze, Italy \\ ' Grassland Ecosystem Research Unit, French National Institute for Agricultural Research, UREP-INRA, Clermont-Ferrand, France \\ ${ }^{\mathrm{d}}$ Consiglio per la Ricerca e la Sperimentazione in Agricoltura, CRA-VIV, Pescia (PT), Italy
}

\section{A R T I C L E I N F O}

\section{Article history:}

Received 16 October 2012

Received in revised form 12 March 2013

Accepted 21 March 2013

\section{Keywords:}

Gerbera

Greenhouse crops

Model

$\mathrm{NaCl}$ salinity

Penman-Monteith equation

Transpiration

\begin{abstract}
A B S T R A C T
Gerbera plants were grown in semi-closed rockwool culture under greenhouse conditions in different seasons in a Mediterranean climate. The plants were irrigated using either fresh $\left(\mathrm{FW} ; 1.0 \mathrm{~mol} \mathrm{~m}^{-3} \mathrm{NaCl}\right)$ or moderately saline ( $\mathrm{SW} ; 9.0 \mathrm{~mol} \mathrm{~m}^{-3} \mathrm{NaCl}$ ) water. In autumn, $\mathrm{NaCl}$ concentration did not influence significantly plant growth, flower production and transpiration (E), which instead were reduced in spring in the plants irrigated with SW. In both seasons, water salinity did not affect leaf stomatal resistance $\left(r_{1}\right)$, which was determined by the inversion of the Penman-Monteith (PM) equation or measured with a diffusion porometer. The PM formula and two regression equations were calibrated and validated for estimating the hourly rate of daytime transpiration $\left(E_{\mathrm{d}}\right)$; a regression model was also fit to nocturnal transpiration $\left(E_{\mathrm{n}}\right)$. Regression models predicted $E_{\mathrm{d}}$ as a function of vapour pressure deficit (VPD) and/or the radiation intercepted by the canopy. Leaf area index (LAI), which is required by all the equations, was modelled as function of crop thermal time (i.e. growing degree days). The PM model predicted $E_{\mathrm{d}}$ using a constant value of $r_{1}$. Model calibration and validation were performed using independent datasets. The irrigation with FW or SW did not require a different calibration of transpiration models. Both PM formula and regression equations provided accurate estimates of $E_{\mathrm{d}}$; fitted equations explained between $80 \%$ and $96 \%$ of the variance in measured $E_{\mathrm{d}}$. A linear regression of $E_{\mathrm{n}}$ against (LAI.VPD) accounted for $92 \%$ of measured $E_{\mathrm{n}}$.
\end{abstract}

(c) 2013 Elsevier B.V. All rights reserved.

\section{Introduction}

Greenhouse crops are generally over-irrigated and this results in water loss and environmental degradation due to fertilizers leaching (Vox et al., 2010). A major cause of over-irrigation is inadequate scheduling, which often is based on grower's experience rather than on accurate assessment of crop water requirements (Pardossi and Incrocci, 2011; Thompson et al., 2007).

Leaf transpiration $(E)$ is the primary process affecting plant water uptake $(W)$ and hence its knowledge is necessary to determine crop water needs. In greenhouse crops, particularly in substrate culture, irrigation control requires the determination of $E$ over short time intervals (hourly or less). If $E$ is known as a function of climatic variables, $E$ models can be easily implemented for

\footnotetext{
* Corresponding author at: Viale delle Piagge 23, 56124 Pisa, Italy. Tel.: +39 0502216526; fax: +390502216524.

E-mail address: alberto.pardossi@agr.unipi.it (A. Pardossi).
}

automated irrigation control. Modelling $E$ can also provide a softsensor in an early warning system for growers (Elings and Voogt, 2007). For instance, a reduction of actual $E$ with respect to the predictions may indicate alterations of plant water status resulting from a technical failure of irrigation system, mistakes in fertigation management and/or the occurrence of root diseases.

The use of the Penman-Monteith (PM) equation (Allen et al., 1998 ) provides accurate $E$ prediction; however, it requires several input parameters that are difficult to estimate, such as leaf stomatal resistance $\left(r_{1}\right)$. Several authors (e.g. Baille et al., 1994a; Carmassi et al., 2007a; Kittas et al., 1999) proposed simplified forms of the PM formula based on the assumption of constant $r_{1}$.

The PM equation and its simplified versions have been used for predicting $E$ in a variety of greenhouse crops, such as cucumber (Medrano et al., 2005), geranium (Montero et al., 2001), lettuce (Pollet et al., 2000), rose (Baille et al., 1994b; Kittas et al., 1999), tomato (Carmassi et al., 2007a; Stanghellini, 1987), zucchini (Rouphael and Colla, 2004) and some pot ornamentals (Bailey et al., 1993; Baille et al., 1994a). However, less attention has been paid 


\begin{tabular}{|c|c|}
\hline \multicolumn{2}{|c|}{ Abbreviation } \\
\hline \multicolumn{2}{|c|}{ Symbol or abbreviation } \\
\hline$A$ & empirical coefficient in Eqs. (9) and (12) \\
\hline$B$ & $\begin{array}{l}\text { empirical coefficient in Eqs. (9) and (13) } \\
\left(\mathrm{kg} \mathrm{m}^{-2} \mathrm{~h}^{-1} \mathrm{kPa}^{-1}\right)\end{array}$ \\
\hline$c_{\mathrm{p}}$ & specific heat of the air $\left(\mathrm{J} \mathrm{kg}^{-1} \mathrm{~K}^{-1}\right)$ \\
\hline$d$ & leaf dimensions (m) \\
\hline E & transpiration rate $\left(\mathrm{kg} \mathrm{m}^{-2} \mathrm{~h}^{-1}\right.$ or $\mathrm{kg} \mathrm{m}^{-2}$ day $\left.^{-1}\right)$ \\
\hline$E_{24 \mathrm{~h}}$ & crop transpiration in the $24 \mathrm{~h}$ period $\left(\mathrm{kg} \mathrm{m}^{-2} \mathrm{day}^{-1}\right)$ \\
\hline$e_{\mathrm{a}}$ & air vapour pressure (kPa) \\
\hline$e_{\mathrm{a}}^{*}$ & saturated air vapour pressure ( $\mathrm{kPa})$ \\
\hline EC & electrical conductivity $\left(\mathrm{dS} \mathrm{m}^{-1}\right)$ \\
\hline$E_{\mathrm{d}}$ & daytime transpiration rate $\left(\mathrm{kg} \mathrm{m}^{-2} \mathrm{~h}^{-1}\right)$ \\
\hline$E_{\mathrm{n}}$ & nocturnal crop transpiration rate $\left(\mathrm{kg} \mathrm{m}^{-2} \mathrm{~h}^{-1}\right)$ \\
\hline FW & fresh water \\
\hline$g$ & gravity acceleration $\left(\mathrm{m} \mathrm{s}^{-2}\right)$ \\
\hline GDD & growing degree days $\left({ }^{\circ} \mathrm{C}\right)$ \\
\hline Gr & Grashof number \\
\hline$h$ & heat transfer coefficient $\left(\mathrm{W} \mathrm{m}^{-2} \mathrm{~K}^{-1}\right)$ \\
\hline$I$ & indoor global radiation $\left(\mathrm{MJ} \mathrm{m}^{-2} ; \mathrm{W} \mathrm{m}^{-2}\right)$ \\
\hline$I_{\mathrm{c}}$ & $\begin{array}{l}\text { global radiation intercepted by crop canopy } \\
\left(\mathrm{MJ} \mathrm{m}^{-2} ; \mathrm{W} \mathrm{m}^{-2}\right)\end{array}$ \\
\hline$I_{\mathrm{n}}$ & net radiation $\left(\mathrm{MJ} \mathrm{m}^{-2} ; \mathrm{W} \mathrm{m}^{-2}\right)$ \\
\hline$k$ & light extinction coefficient (dimensionless) \\
\hline$k_{\mathrm{c}}$ & thermal conductivity of air $\left(\mathrm{W} \mathrm{m}^{-1} \mathrm{~K}^{-1}\right)$ \\
\hline lt & leaf length (m) \\
\hline LAI & leaf area index \\
\hline NS & nutrient solution \\
\hline PM & Penman-Monteith \\
\hline$r_{\mathrm{a}}$ & $\begin{array}{l}\text { aerodynamic resistance of the canopy to vapour } \\
\text { transfer }\left(\mathrm{s} \mathrm{m}^{-1}\right)\end{array}$ \\
\hline$r_{\mathrm{c}}$ & canopy resistance $\left(\mathrm{s} \mathrm{m}^{-1}\right)$ \\
\hline $\operatorname{Re}$ & Reynolds number \\
\hline$r_{1}$ & leaf stomatal resistance $\left(\mathrm{s} \mathrm{m}^{-1}\right)$ \\
\hline SW & saline water \\
\hline$T_{\mathrm{a}}$ & air temperature $\left({ }^{\circ} \mathrm{C}\right)$ \\
\hline$T_{1}$ & leaf temperature $\left({ }^{\circ} \mathrm{C}\right)$ \\
\hline$u$ & air velocity $\left(\mathrm{m} \mathrm{s}^{-1}\right)$ \\
\hline VPD & vapour pressure deficit (kPa) \\
\hline$v$ & kinematic viscosity of air $\left(\mathrm{m}^{2} \mathrm{~s}^{-1}\right)$ \\
\hline$w$ & leaf width (m) \\
\hline W & water uptake $\left(\mathrm{kg} \mathrm{m}^{-2}\right)$ \\
\hline$\beta$ & thermal expansion coefficient of air $\left(\mathrm{K}^{-1}\right)$ \\
\hline$\Delta$ & $\begin{array}{l}\text { slope of the relationship of saturation vapour pres- } \\
\text { sure on temperature }\left(\mathrm{kPa}^{\circ} \mathrm{C}^{-1}\right)\end{array}$ \\
\hline$\gamma$ & psychrometric constant $\left(\mathrm{kPa}^{\circ} \mathrm{C}^{-1}\right)$ \\
\hline$\lambda$ & latent heat of water vaporization $\left(\mathrm{J} \mathrm{kg}^{-1}\right)$ \\
\hline$\rho$ & air density $\left(\mathrm{kg} \mathrm{m}^{-3}\right)$ \\
\hline$\Omega$ & decoupling coefficient \\
\hline
\end{tabular}

to cut-flower gerbera (Gerbera jamesonii H. Bolus), one of the most important greenhouse ornamental crops (Vidalie, 2007). To the best of our knowledge, only a short paper on modelling $E$ in gerbera was published in the proceedings of an international symposium (Marfà et al., 2000).

In this work, we used the PM model and two regression equations to predict $E$ of gerbera plants grown in semi-closed substrate (rockwool) culture under the typical greenhouse conditions of Mediterranean area. With respect to the paper published by Marfà et al. (2000), different approaches were used to estimate leaf area index (LAI) and $r_{1}$. Besides, we investigated the effect of $\mathrm{NaCl}$ salinity on crop growth and water relations, and its possible influence on modelling $E$. In many regions, particularly in the Mediterranean area, protected horticulture is increasingly facing the salinization of water resources (Pardossi et al., 2004) and the knowledge of crop response to salinity is important for optimal crop management (Stanghellini et al., 2007). Greenhouse crops cannot be grown with highly saline water for being profitable (Stanghellini et al., 2007). Therefore, in our study a moderately saline water $(\mathrm{NaCl}$ concentration of $9.0 \mathrm{~mol} \mathrm{~m}^{-3}$ against $1.0 \mathrm{~mol} \mathrm{~m}^{-3}$ in the fresh or control water) was tested.

\section{Materials and methods}

\subsection{Plant material and growing conditions}

Gerbera (cv. Vital) plants were cultivated between 29 May 2004 and 30 November 2005 in a glasshouse at the University of Pisa (Pisa, Italy, latitude $43^{\circ} 43^{\prime} \mathrm{N}$, longitude $10^{\circ} 23^{\prime} \mathrm{E}$ ). The glasshouse was equipped with automated side and roof windows (with insect screens) and heating system; ventilation and minimum temperatures were 27 and $15^{\circ} \mathrm{C}$, respectively. The glasshouse was heated sporadically (generally only in the night) and was covered by black plastic net (30\% shading rate) from late May to the end of August in both years.

The plants were grown in rockwool slabs at a density of approximately 5 plants $\mathrm{m}^{-2}$. The glasshouse had six separate growing units, each consisting of two benches with 12 slabs ( 48 plants in total) and an 801 mixing tank collecting the drainage NS. The total amount of recirculating NS, including the substrate and the mixing tank, was approximately 1501 (i.e. $15.61 \mathrm{~m}^{-2}$ expressed per unit of ground area). In order to compensate crop $W$, the mixing tank was automatically refilled with full-strength NS. Drip irrigation was controlled by a timer; the plants were watered 2-6 times a day, depending on growth stage and seasons, with a watering dose of $1.5-2.01 \mathrm{~m}^{-2}$ (leaching fraction was roughly $0.30-0.50$ ).

Nutrient solution was made up with either fresh water (FW; $1.0 \mathrm{~mol} \mathrm{~m}^{-3} \mathrm{NaCl}$ ) or saline water (SW; $\left.9.0 \mathrm{~mol} \mathrm{~m}^{-3} \mathrm{NaCl}\right)$, which were prepared by dissolving appropriate doses of $\mathrm{NaCl}$ to rainwater. Each treatment was applied to three separate growing units (replicates). All the plants were initially grown with FW; SW was applied at the beginning of September 2004. The EC of the NS prepared with FW and SW was 1.45 and $2.25 \mathrm{dS} \mathrm{m}^{-1}$, respectively. The nutrient solution also contained $9.1 \mathrm{~mol} \mathrm{~m}^{-3} \mathrm{NO}_{3}{ }^{-}, 1.0 \mathrm{~mol} \mathrm{~m}^{-3}$ $\mathrm{H}_{2} \mathrm{PO}_{4}^{-}, 4.3 \mathrm{~mol} \mathrm{~m}^{-3} \mathrm{~K}^{+}, 1.1 \mathrm{~mol} \mathrm{~m}^{-3} \mathrm{Mg}^{2+}, 3.0 \mathrm{~mol} \mathrm{~m}^{-3} \mathrm{Ca}^{2+}$, plus Hoagland concentration of trace elements. In each growing unit, NS was checked almost daily for $\mathrm{EC}$ and $\mathrm{pH}$; the latter was kept between 5.5 and 6.0 by frequent addition of sulphuric acid. Nutrient solution was discharged whenever EC exceeded 3.0 or $4.0 \mathrm{dS} \mathrm{m}^{-1}$ in the FW and SW cultures, respectively.

Older leaves were recurrently removed following growers' practice and in February of 2005 the plants were intensively defoliated in order to stimulate a new flush of growth.

\subsection{Determinations}

Crop growth, flower production and water relations were monitored in three periods (Table 1): (i) between 22 September 2004 and 9 January 2005 (110 days); (ii) between 11 April and 2 July 2005 (83 days); (iii) between 10 October and 20 November 2005 (42 days). In the third period, only $E$ and $W$ were measured.

Fresh and recirculating NS was periodically sampled for laboratory analyses of macronutrients and $\mathrm{Na}$, as reported by Massa et al. (2010).

Crop shoot biomass and LAI were determined by sampling six individual plants from each treatment on 9 January and 3 July 2005. The plants were separated in leaves and inflorescences (stem and flower head), which were dried to constant weight at $80^{\circ} \mathrm{C}$ 
Table 1

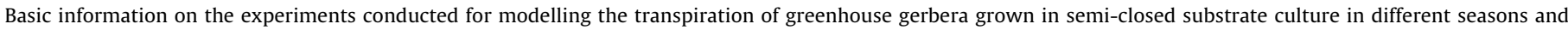
irrigated with fresh (FW; $1.0 \mathrm{~mol} \mathrm{~m}^{-3} \mathrm{NaCl}$ ) or saline (SW; $9.0 \mathrm{~mol} \mathrm{~m}^{-3} \mathrm{NaCl}$ ) water. In autumn 2005 , all gerbera plants were irrigated with $\mathrm{FW}$.

\begin{tabular}{|c|c|c|c|c|c|c|}
\hline \multirow[t]{2}{*}{ Season (start date) } & \multirow{2}{*}{$\begin{array}{l}\text { Days of } \\
\text { observation }\end{array}$} & \multirow{2}{*}{$\begin{array}{l}\text { Mean air } \\
\text { temperature } \\
\left({ }^{\circ} \mathrm{C}\right)\end{array}$} & \multirow{2}{*}{$\begin{array}{l}\text { Daily solar } \\
\text { radiation } \\
\left(\mathrm{MJ} \mathrm{m}^{-2}\right)\end{array}$} & \multirow{2}{*}{$\begin{array}{l}\text { Mean VPD } \\
(\mathrm{kPa})\end{array}$} & \multicolumn{2}{|c|}{ EC oscillation $\left(\mathrm{dS} \mathrm{m}^{-1}\right)$} \\
\hline & & & & & FW & SW \\
\hline Autumn 2004 (22 September 2004) & 110 & 17.4 & 2.27 & 0.30 & $2.48-3.42$ & $3.08-4.05$ \\
\hline Spring 2005 (11 April 2005) & 83 & 22.6 & 9.87 & 1.02 & $1.97-3.03$ & $2.78-4.21$ \\
\hline Autumn 2005 (10 October 2005) & 42 & 16.6 & 3.97 & 0.34 & $2.18-3.02$ & - \\
\hline
\end{tabular}

in a ventilated oven. Total biomass accumulation was computed including the leaves and the flowers detached in occasion of pruning and harvesting. Leaf area index was also determined weekly by non-destructive measurements of leaf dimensions (maximum length and width) of individual leaves using the equation reported by Carmassi et al. (2007b).

Daily $W$ was determined by recording with a water meter the amount of NS used to refill the mixing tank. Hourly $E$ was measured by weighing a tray with six plants using an electronic balance. The balance (capacity: $30 \mathrm{~kg}$; resolution: $\pm 0.001 \mathrm{~kg}$ ) was placed in the centre of a bench with other plants in order to form a continuous canopy. We assumed that weight loss was equal to $E$ as evaporation from substrate was prevented by plastic film. Indoor incident radiation $(I)$, air temperature $\left(T_{\mathrm{a}}\right)$, wet and dry bulb air temperature, and calculated vapour pressure deficit (VPD) were recorded with a weather station located in the central part of the glasshouse. Both climate sensors and electronic balance were scanned every minute by a data logger and averages were made over 60 min time periods. Data recorded in occasion of irrigation events (until $20 \mathrm{~min}$ after the start of watering, when the drainage from the tray had terminated) and $E$ values below $0.005 \mathrm{~kg} \mathrm{~m}^{-2} \mathrm{~h}^{-1}$ were discarded. As only one balance was available, crop $E$ was monitored in each salinity treatment every other week. Daytime $\left(I \geq 25 \mathrm{~W} \mathrm{~m}^{-2}\right)$ values of $E\left(E_{\mathrm{d}}\right)$ were separated from those measured during the night $\left(E_{\mathrm{n}}\right.$; $I<25 \mathrm{~W} \mathrm{~m}^{-2}$ ); actually, for $E_{\mathrm{d}}$ modelling we used the data recorded between 08.00 a.m. and 05.00 p.m. $(10 \mathrm{~h})$ in autumn, and between 07.00 a.m. and 07.00 p.m. (13 h) in spring.

On some days in autumn 2004 and in spring 2005, we measured leaf stomatal resistance $\left(r_{1}\right)$ with a diffusion porometer (MK, Delta-T Devices, Cambridge, UK). The measurements were taken between $11.00 \mathrm{a} . \mathrm{m}$. and 01.00 p.m.; in each treatment, 2-3 leaves were sampled from 4 to 6 individual plants.

Leaf temperature $\left(T_{1}\right)$ and air velocity $\left(u, \mathrm{~m} \mathrm{~s}^{-1}\right)$ were measured discontinuously with a portable infrared thermometer and a hotwire anemometer.

\subsection{Transpiration models}

The first model was derived from the PM equation (Allen et al., 1998; Baille et al., 1994b):

$\lambda \cdot E=\frac{\Delta \cdot I_{\mathrm{c}}}{\Delta+\gamma^{*}}+\frac{\left(\rho \cdot c_{\mathrm{p}} / r_{\mathrm{a}}\right) \cdot\left(e_{\mathrm{a}}^{*}-e_{\mathrm{a}}\right)}{\Delta+\gamma^{*}}$

where crop $E\left(\mathrm{~kg} \mathrm{~m}^{-2} \mathrm{~h}^{-1}\right)$ is based on ground area, $\lambda\left(\mathrm{J} \mathrm{kg}^{-1}\right)$ is the latent heat of vaporization of water, $I_{\mathrm{c}}\left(\mathrm{W} \mathrm{m}^{-2}\right)$ is the radiation intercepted by canopy, $\rho\left(\mathrm{kg} \mathrm{m}^{-3}\right)$ is air density, $c_{\mathrm{p}}\left(\mathrm{J} \mathrm{kg}^{-1} \mathrm{~K}^{-1}\right)$ is the specific heat of air at constant pressure, $e_{\mathrm{a}}(\mathrm{kPa})$ is the air vapour pressure, $e_{\mathrm{a}}^{*}(\mathrm{kPa})$ is the saturated air vapour pressure, $r_{\mathrm{a}}\left(\mathrm{s} \mathrm{m}^{-1}\right)$ is the aerodynamic resistance to vapour transfer, $\Delta\left(\mathrm{kPa}^{\circ} \mathrm{C}^{-1}\right)$ is the slope of the relationship of saturation vapour pressure on temperature, $\gamma^{*}=\gamma\left(1+r_{\mathrm{c}} / r_{\mathrm{a}}\right)$ where $\gamma\left(\mathrm{kPa}^{\circ} \mathrm{C}^{-1}\right)$ is the psychrometric constant, and $r_{c}\left(\mathrm{~s} \mathrm{~m}^{-1}\right)$ is the mean canopy resistance.

The term $I_{\mathrm{c}}$ in Eq. (1) was calculated as:

$I_{\mathrm{C}}=I \cdot\left(1-\exp ^{-k \cdot \mathrm{LAI}}\right)$ where $k$ (dimensionless) is the light interception coefficient. This coefficient was determined on the basis of Lambert-Beer's law from the radiation measured with a piranometer placed above and below the crop row (Nobel and Long, 1985).

In Eq. (2), $I$ was used instead of net radiation $\left(I_{n}\right)$ because net radiometer was not available. This was possible because in unheated greenhouses $I_{n}$ matches I during the light period (Bailey et al., 1993; Baille et al., 1994a). In another experiment conducted in 2006 with gerbera grown in the same glasshouse (unpublished results), a close linear relationship was found between $I_{\mathrm{n}}$ and $I\left(I_{\mathrm{n}}=0.981 I ; R^{2}=0.902 ; n=487\right)$ in the range between 25 and $545 \mathrm{~W} \mathrm{~m}^{-2}$.

Leaf area index was estimated as a function of growing degree days (GDD) assuming a base temperature of $8^{\circ} \mathrm{C}$.

Canopy resistance was computed as the ratio between $r_{1}$ and LAI while $r_{\mathrm{a}}$ was calculated as follows:

$r_{\mathrm{a}}=\frac{\rho \cdot c_{\mathrm{p}}}{2 \cdot \mathrm{LAI} \cdot h}$

where $h\left(\mathrm{~W} \mathrm{~m}^{-2} \mathrm{~K}^{-1}\right)$ is the heat transfer coefficient for individual leaves (Bailey et al., 1993).

There is no consensus on how heat is transferred under greenhouse conditions and hence $h$ was calculated according to the free (McAdams, 1954), forced (Gröber and Erk, 1961) or mixed convection (Stanghellini, 1987) using the Grashof (Gr) and Reynolds (Re) numbers (Bailey et al., 1993). In a preliminary data analysis, we found that the best predictions of $E$ were obtained when $h$ was computed assuming a mixed convection, as follows:

$h=0.37 \cdot\left(\frac{k_{\mathrm{c}}}{d}\right) \cdot\left(\mathrm{Gr}+6.92 \mathrm{Re}^{2}\right)^{1 / 4}$

where $k_{\mathrm{c}}\left(\mathrm{W} \mathrm{m}^{-1} \mathrm{~K}^{-1}\right)$ is the thermal conductivity of air and $d(\mathrm{~m})$ is the leaf dimension determined as:

$d=\frac{2}{(1 / l t)+(1 / w)}$

where $l t(\mathrm{~m})$ and $w(\mathrm{~m})$ are, respectively, the length and the width of the leaves.

The numbers of Grashof and Reynolds correspond to the air flow occurring in free and forced convection, respectively.

The Grashof number was computed as a function of the difference between $T_{1}$ and $T_{\mathrm{a}}$ :

$\mathrm{Gr}=\frac{\beta \cdot g \cdot d^{3} \cdot\left|T_{1}-T_{\mathrm{a}}\right|}{v^{2}}$

where $\beta\left(\mathrm{K}^{-1}\right)$ is the thermal expansion coefficient of air, $g\left(\mathrm{~m} \mathrm{~s}^{-2}\right.$ ) is the acceleration due to gravity and $v\left(\mathrm{~m}^{2} \mathrm{~s}^{-1}\right)$ is the kinematic viscosity of air.

The Reynolds number (Re) was obtained from $u, d$ and $v$, as follows

$\operatorname{Re}=\frac{u \cdot d}{v}$

Leaves are generally very thin, thus the temperature of the upper and lower leaf surface was assumed equal. 

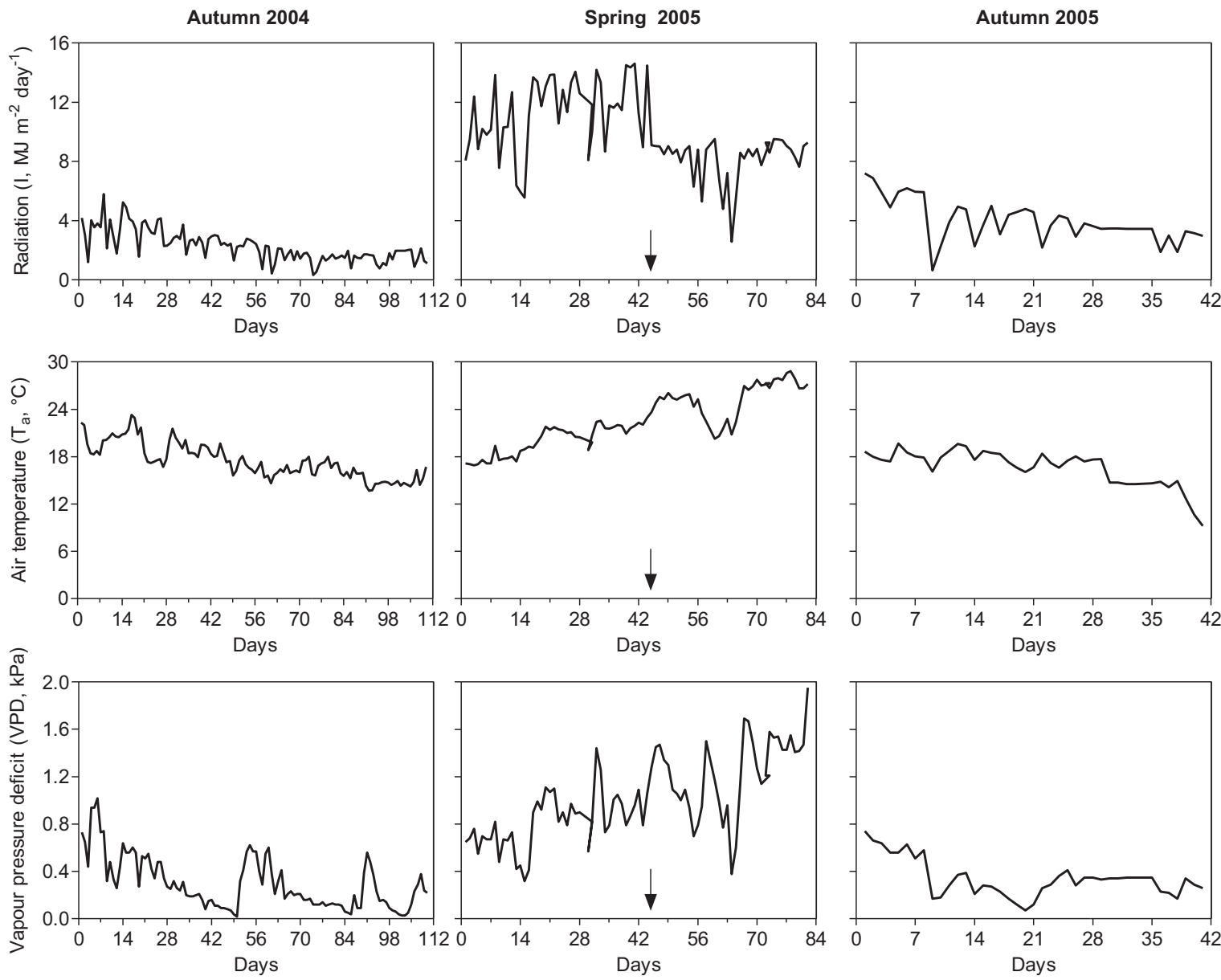

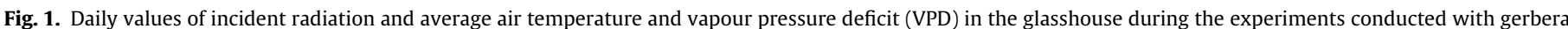

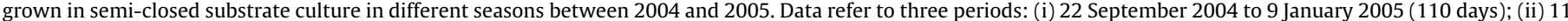

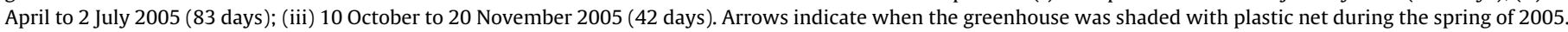

The dimensionless decoupling coefficient $(\Omega)$ was calculated to analyze the dependence of $E_{\mathrm{d}}$ on atmospheric environment and stomatal opening (Jarvis and McNaughton, 1986), namely:

$\Omega=\frac{1}{1+(\gamma /(\Delta+\gamma)) \cdot\left(r_{c} / r_{\mathrm{a}}\right)}$

Transpiration rate was also modelled using the equation proposed by Baille et al. (1994a):

$E_{\mathrm{d}}=A \cdot \frac{I_{\mathrm{c}}}{\lambda}+B \cdot \mathrm{LAI} \cdot \mathrm{VPD}$

The coefficients $A$ (dimensionless) and $B\left(\mathrm{~kg} \mathrm{~m}^{-2} \mathrm{~h}^{-1} \mathrm{kPa}^{-1}\right)$ were obtained by regressing measured $E$ against $I_{\mathrm{c}}\left(\mathrm{MJ} \mathrm{m}^{-2} \mathrm{~h}^{-1}\right)$ and (LAI.VPD).

\subsection{Statistics}

The influence of growing season and irrigation water salinity on crop growth, flower production and seasonal $W$ was assessed through ANOVA. Calibration and validation of $E$ models was performed using independent datasets. Model accuracy was assessed by regression analysis of predictions against measurements; we computed the slope and the intercept of the linear regression, the determination coefficient $\left(R^{2}\right)$, the standard error of estimates (SEE), the mean percentage error (MPE) and the mean absolute percentage error (MAPE). Statistical analysis was performed with Statgraphics Centurion XV (Statpoint Technologies, Inc., Warrenton, VA, USA).

\section{Results and discussion}

\subsection{Growing conditions}

Fig. 1 shows the seasonal variations of daily values of $I, T_{\mathrm{a}}$ and VPD. Daily averages of $I, T_{\mathrm{a}}$ and VPD were, respectively $2.27 \mathrm{MJ} \mathrm{m}^{-2}$ day $^{-1}, 17.4{ }^{\circ} \mathrm{C}$ and $0.30 \mathrm{kPa}$ in the autumn of 2004 ; $9.87 \mathrm{MJ} \mathrm{m}^{-2} \mathrm{day}^{-1}, 22.6^{\circ} \mathrm{C}$ and $1.02 \mathrm{kPa}$ in the spring of 2005; $3.97 \mathrm{MJ} \mathrm{m}^{-2} \mathrm{day}^{-1}, 16.6^{\circ} \mathrm{C}$ and $0.34 \mathrm{kPa}$ in the autumn of 2005 (Table 1). Over the daylight period, $I, T_{\mathrm{a}}$ and VPD ranged, respectively; from 0.10 to $0.47 \mathrm{MJ} \mathrm{m}^{-2} \mathrm{~h}^{-1}$, from 17.1 to $23.2^{\circ} \mathrm{C}$ and from 0.22 to $0.95 \mathrm{kPa}$ in autumn; from 0.14 to $1.10 \mathrm{MJ} \mathrm{m}^{-2} \mathrm{~h}^{-1}$, from 20.6 to $28.8^{\circ} \mathrm{C}$ and from 0.56 to $2.70 \mathrm{kPa}$ in spring. Despite glasshouse shading, in late spring and summer $T_{\mathrm{a}}$ exceeded frequently $30^{\circ} \mathrm{C}$ during sunny hours. Significant positive correlations were found between $I$ and $T_{\mathrm{a}}\left(R^{2}=0.328 ; n=1374\right)$ or $\operatorname{VPD}\left(R^{2}=0.381\right)$, and between $T_{\mathrm{a}}$ and $\operatorname{VPD}\left(R^{2}=0.738\right)$. In the night, significant correlation $\left(R^{2}=0.563 ; n=908\right)$ was found between $T_{\mathrm{a}}$ and VPD.

In the FW culture, the EC of recirculating NS ranged from 2.48 to $3.42 \mathrm{dS} \mathrm{m}^{-1}$ with a mean value of $2.78 \mathrm{dS} \mathrm{m}^{-1}$ in the autumn of 2004 , and from 1.97 and $3.03 \mathrm{dS} \mathrm{m}^{-1}$ with a mean value of $2.28 \mathrm{dS} \mathrm{m}^{-1}$ in the spring of 2005; NS solution was discharged on two occasions in autumn and on four occasions in spring. In the SW culture, EC oscillated between 2.78 and $4.21 \mathrm{dS} \mathrm{m}^{-1}$ with a mean value of $3.62 \mathrm{dS} \mathrm{m}^{-1}$ in autumn, when NS was discharged four times, and between 2.78 and $4.21 \mathrm{dS} \mathrm{m}^{-1}$ with a mean value of $3.69 \mathrm{dS} \mathrm{m}^{-1}$ in the spring of 2005 , when NS was discharged eight times. 
Table 2

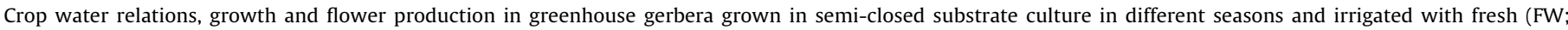

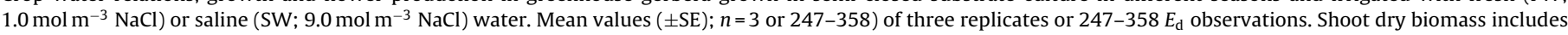

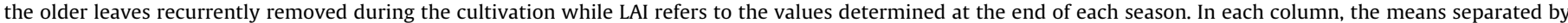

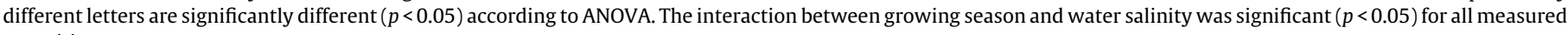
quantities.

\begin{tabular}{|c|c|c|c|c|c|c|c|}
\hline Season & $\begin{array}{l}\text { Water } \\
\text { source }\end{array}$ & $\begin{array}{l}\text { Seasonal water } \\
\text { uptake } \\
\left(\mathrm{kg} \mathrm{m}^{-2}\right)\end{array}$ & $\begin{array}{l}\text { Mean daily } \\
\text { water uptake } \\
\left(\mathrm{kg} \mathrm{m}^{-2} \text { day }^{-1}\right)\end{array}$ & $\begin{array}{l}\text { Mean hourly rate } \\
\text { of daytime } \\
\text { transpiration }\left(E_{\mathrm{d}}\right. \\
\left.\mathrm{kg} \mathrm{m}^{-2} \text { day }^{-1}\right)\end{array}$ & $\begin{array}{l}\text { Shoot dry } \\
\text { biomass } \\
\left(\mathrm{kg} \mathrm{m}^{-2}\right)\end{array}$ & $\begin{array}{l}\text { Leaf area } \\
\text { index (LAI) }\end{array}$ & 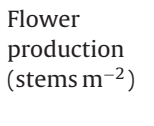 \\
\hline Autumn 2004 (110 days) & $\begin{array}{l}\text { FW } \\
\text { SW }\end{array}$ & $\begin{array}{l}64.9 \pm 3.7 c \\
56.1 \pm 3.0 d\end{array}$ & $\begin{array}{l}0.59 \pm 0.07 c \\
0.51 \pm 0.05 c\end{array}$ & $\begin{array}{l}0.053 \pm 0.004 c \\
0.049 \pm 0.004 c\end{array}$ & $\begin{array}{l}0.39 \pm 0.02 c \\
0.39 \pm 0.06 c\end{array}$ & $\begin{array}{l}1.02 \pm 0.08 c \\
1.04 \pm 0.06 c\end{array}$ & $\begin{array}{l}58.2 \pm 5.4 c \\
50.8 \pm 7.8 c\end{array}$ \\
\hline Spring 2005 (83 days) & $\begin{array}{l}\text { FW } \\
\text { SW }\end{array}$ & $\begin{array}{l}222.4 \pm 8.2 \mathrm{a} \\
168.5 \pm 4.6 \mathrm{~b}\end{array}$ & $\begin{array}{l}2.68 \pm 0.10 a \\
2.03 \pm 0.07 b\end{array}$ & $\begin{array}{l}0.203 \pm 0.003 a \\
0.136 \pm 0.003 b\end{array}$ & $\begin{array}{l}0.71 \pm 0.01 a \\
0.50 \pm 0.05 b\end{array}$ & $\begin{array}{l}2.43 \pm 0.19 a \\
1.40 \pm 0.20 b\end{array}$ & $\begin{array}{r}104.5 \pm 0.8 \mathrm{a} \\
76.3 \pm 9.1 \mathrm{~b}\end{array}$ \\
\hline
\end{tabular}

In all the cultures, salinity build-up in the recirculating NS was principally due to $\mathrm{NaCl}$ accumulation (data not shown) as found by other authors in closed-loop soilless cultures (Massa et al., 2010; Savvas et al., 2008). Mean concentrations of both macronutrients and micronutrients in the recirculating NS were generally close to their content in the refill NS (data not shown).

\subsection{Crop growth and production}

$\mathrm{NaCl}$ salinity reduces crop growth and production in sensitive species (Volkmar et al., 1998) due to its negative effects on water and mineral relations, carbon assimilation and biomass partitioning. Crop response to salinity depends on cultivar and growing conditions (e.g. Baas et al., 1995; De Kreij and van Os, 1989; Sonneveld et al., 1999). Gerbera is a crop moderately sensitive to salinity (Baas et al., 1995; Sonneveld et al., 1999). According to these authors, the maximum salinity (expressed as the EC of nutrient solution) without yield reduction in substrate-grown gerbera is $1.5-2.8 \mathrm{dS} \mathrm{m}^{-1}$; the flower production decreased by $10 \%$ for each unit increase of EC above the threshold. In our work, gerbera plants appeared much more sensitive to $\mathrm{NaCl}$ salinity, at least in spring, since an increase of $1.41 \mathrm{dS} \mathrm{m}^{-1}$ in average EC of the recirculating NS resulted in a reduction of flower production of about $19 \%$ (Table 2).

In spring, the use of SW also reduced significantly shoot dry weight and LAI as compared to FW (Table 2). The reduction of LAI was due to an inhibition of both leaf expansion and formation. In fact, at the end of the season the leaves of non-salinized and salinized plants were $26.5 \pm 0.50$ and $21.50 \pm 0.60$, respectively.

Negative effects of salinity on crop growth and/or fruit yield were alleviated in melon (An et al., 2002) and tomato (Li et al., 2001) when the plants were grown under high relative humidity, which reduced $E$ compared to standard conditions.

\subsection{Leaf area model}

Modelling $E$ requires the determination of LAI, which can be achieved by direct (destructive or non-destructive) measurements or simulation models. In both greenhouse and field crops, LAI development is often modelled as a function of GDD using non-linear (e.g. exponential and sigmoid) equations since crop LAI tends to reach a plateau (Thornley and Johnson, 1990). In our study, LAI increased with time in spring (Fig. 2) whereas it remained fairly constant around 1.0 in autumn, when the formation of new leaves was balanced by the weekly removal of older leaves. Compared to the plants irrigated with SW, those grown with FW showed faster leaf development and reached a maximum LAI around 2.4 within eight weeks from the start of observations (Fig. 2). In the
FW crop, the response of LAI to GDD was adequately described by an exponential function (Eq. (10); $R^{2}=0.986 ; n=11$ ):

$\mathrm{LAI}=(1.043-2.448) \cdot \exp ^{-0.0066 \cdot G D D}+2.448$

On the contrary, in salinized plants LAI never reached a plateau during the study period (Fig. 2). A linear model fitted well measured LAI in this culture (Eq. (11); $R^{2}=0.938 ; n=11$ ):

$\mathrm{LAI}=0.9354+0.0006 \cdot \mathrm{GDD}$

Transpiration model also required to estimate $I_{\mathrm{C}}$ from LAI and $k$ (Eq. (2)). The light extinction coefficient was determined when LAI was $1.03 \pm 0.06$ and $1.96 \pm 0.08$, with similar results. It was $0.60 \pm 0.02(n=40)$, in agreement with Marfà et al. (2000).

\subsection{Crop water relations}

The reliability of the electronic balance used for measuring $E$ was assessed by comparing daily-cumulated $E\left(E_{24 h}\right.$; ) of the six test-plants to the daily $W$ of the whole growing unit (48 plants). A significant $\left(R^{2}=0.885 ; n=176\right)$ linear relationship was found between $E_{24}$ h and $W$ with a slope close to $1(0.986)$ and a negligible intercept $\left(0.064 \mathrm{~kg} \mathrm{~m}^{-2} \mathrm{day}^{-1}\right)$.

Crop water uptake was not affected by $\mathrm{NaCl}$ salinity in autumn (Table 2); daily $W$ was as high as $1.78 \mathrm{~kg} \mathrm{~m}^{-2}$ day $^{-1}$ and averaged $0.55 \mathrm{~kg} \mathrm{~m}^{-2} \mathrm{day}^{-1}$. In spring, daily $W$ was significantly higher when the plants were irrigated with FW $\left(2.68 \mathrm{~kg} \mathrm{~m}^{-2}\right.$ day $\left.^{-1}\right)$ instead of $\mathrm{SW}\left(2.03 \mathrm{~kg} \mathrm{~m}^{-2} \mathrm{day}^{-1}\right)$; this resulted in large difference in seasonal $W\left(222.4\right.$ versus $\left.168.5 \mathrm{~kg} \mathrm{~m}^{-2}\right)$.

In the autumn of 2004, the salinity of irrigation water did not influence $E_{\mathrm{d}}$, which ranged between 0.009 and $0.139 \mathrm{~kg} \mathrm{~m}^{-2} \mathrm{~h}^{-1}$

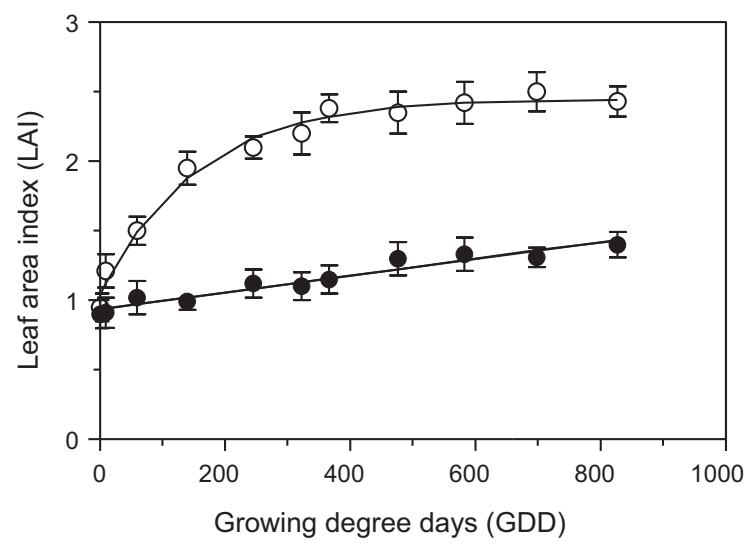

Fig. 2. Relationships between leaf area index (LAI) and growing degree days (GDD) in greenhouse gerbera grown in semi-closed substrate culture in the spring of 2005. The plants were irrigated with fresh (FW; $1.0 \mathrm{~mol} \mathrm{~m}^{-3} \mathrm{NaCl}$ ) or saline (SW; $\left.9.0 \mathrm{~mol} \mathrm{~m}^{-3} \mathrm{NaCl}\right)$ water. Solid lines represent fits to the data $(n=3 ; \pm \mathrm{SE})$ with a linear (SW, filled symbols) or non-linear (FW, empty symbols) function. 
with an average of $0.050 \mathrm{~kg} \mathrm{~m}^{-2} \mathrm{~h}^{-1}$ (Table 2). On the contrary, in the following spring, the use of SW significantly reduced $E_{\mathrm{d}}$, which ranged between 0.020 and $0.354 \mathrm{~kg} \mathrm{~m}^{-2} \mathrm{~h}^{-1}$ in non-salinized plants (average was $0.203 \mathrm{~kg} \mathrm{~m}^{-2} \mathrm{~h}^{-1}$ ) and between 0.015 and $0.270 \mathrm{~kg} \mathrm{~m}^{-2} \mathrm{~h}^{-1}$ in salinized plant (average was $0.136 \mathrm{~kg} \mathrm{~m}^{-2} \mathrm{~h}^{-1}$; Table 2). Approximately, $75 \%$ of cumulative $E_{\mathrm{d}}$ occurred between 10.00 a.m and 03.00 p.m. in autumn, and between 09.00 and 04.00 p.m. in spring (data not shown).

Night transpiration did not exceed $0.013 \mathrm{~kg} \mathrm{~m}^{-2} \mathrm{~h}^{-1}$ in autumn and 0.061 (FW) or 0.045 (SW) $\mathrm{kg} \mathrm{m}^{-2} \mathrm{~h}^{-1}$ in spring and it accounted for about $12 \%$ and $8 \%$ of $E_{24 \mathrm{~h}}$ in autumn and in spring, respectively, in agreement with previous findings in greenhouse cucumber grown in a Mediterranean area (Medrano et al., 2005). In contrast, $E_{\mathrm{n}}$ contributed up to $36 \%$ of $E_{24 \mathrm{~h}}$ in rose plants grown in rockwool during winter in a heated greenhouse (Baille et al., 1994b).

In the light period, $T_{1}$ was $0.2-1.5^{\circ} \mathrm{C}$ lower than $T_{\mathrm{a}}$. In other greenhouse crops such as Ficus benjamina (Bailey et al., 1993), geranium (Montero et al., 2001) and zucchini (Rouphael and Colla, 2004), the $T_{1}-T_{\mathrm{a}}$ difference was up to $5^{\circ} \mathrm{C}$.

Calculated $r_{\mathrm{a}}$, ranged from 80 and $198 \mathrm{~s} \mathrm{~m}^{-1}$; these values are among the typical values reported for standard greenhouse conditions (e.g. Stanghellini, 1987; Baille et al., 1994b).

The analysis of daytime $r_{1}$, as calculated by the inversion of the PM formula, did not disclose any important effect of $\mathrm{NaCl}$ salinity on stomatal behaviour, although on average $r_{1}$ was slightly lower in non-salinized plants than in salinized plants both in autumn $\left(265.1 \pm 17.8 \mathrm{~s} \mathrm{~m}^{-1}\right.$ against $\left.300.5 \pm 18.4 \mathrm{~s} \mathrm{~m}^{-1}\right)$ and in spring $\left(439.9 \pm 14.8 \mathrm{~s} \mathrm{~m}^{-1}\right.$ against $\left.475.4 \pm 15.9 \mathrm{~s} \mathrm{~m}^{-1}\right)$. This result was corroborated by the measurements with a leaf porometer; we never found significant differences in $r_{1}$ between the plants irrigated with FW and those irrigated with SW. The values of $r_{1}$ determined with a porometer ranged between 185 and $367 \mathrm{~s} \mathrm{~m}^{-1}$.

In our work, minimum values of $r_{1}$ were higher than those reported for gerbera (Issa et al., 2001) and other greenhouse crops (e.g. Baille et al., 1994b; Rouphael and Colla, 2004); however, they were in the range determined by Tsirogiannis et al. (2010) in greenhouse gerbera grown in pumice.

The absence of a salinity effect on stomata was in contrast with the reduction of leaf growth observed in salinized plants in the spring of 2005 (Table 2 and Fig. 2). Leaf growth and stomata may show different sensitivity to the water availability in the growing medium (Mohd et al., 2002). It has been reported that leaf growth was more sensitive to moderate salinity (Plaut et al., 2000) or drought (Saab and Sharp, 1989) than transpiration and stomatal conductance.

During daytime $r_{1}$ responded to changes in light conditions and tended to decrease with increasing $I$. However, the large day-today variability in stomata behaviour resulted in poor correlation between $r_{1}$ and climatic variables (data not shown). Mean hourly values of $r_{1}$ changed little in the central hours of the day and were consistently higher in spring than in autumn (Fig. 3, top). This difference was likely due to a reduction of $r_{1}$ induced by higher VPD in spring than in autumn (Figs. 1 and 3, bottom). Stomata are very sensitive to VPD and tend to close in dry atmosphere in order to reduce leaf water loss (Bunce, 1996; Kirkham, 2011). Saturation deficit higher than $1.5-2.0 \mathrm{kPa}$ reduced $E$ in tomato (Boulard et al., 1991) and in rose (Baille et al., 1995).

Crop $W$ and $E_{\mathrm{d}}$ were also monitored for six weeks in the autumn of 2005, when indoor climate conditions were similar to those recorded in the autumn of 2004 (Table 1 and Fig. 1). In this season, the plants were irrigated with FW and half of them were defoliated in order to compare different LAI $(1.95 \pm 0.17$ vs. $1.10 \pm 0.10)$. Daily $W$ and $E_{\mathrm{d}}$ averaged, respectively, $1.22 \pm 0.13 \mathrm{~kg} \mathrm{~m}^{-2} \mathrm{day}^{-1}$ and $0.146 \pm 0.068 \mathrm{~kg} \mathrm{~m}^{-2} \mathrm{~h}^{-1}$ in intact plants, and $0.79 \pm 0.09$ $10 \mathrm{~kg} \mathrm{~m}^{-2} \mathrm{day}^{-1}$ and $0.086 \pm 0.038 \mathrm{~kg} \mathrm{~m}^{-2} \mathrm{~h}^{-1}$ in defoliated plants.
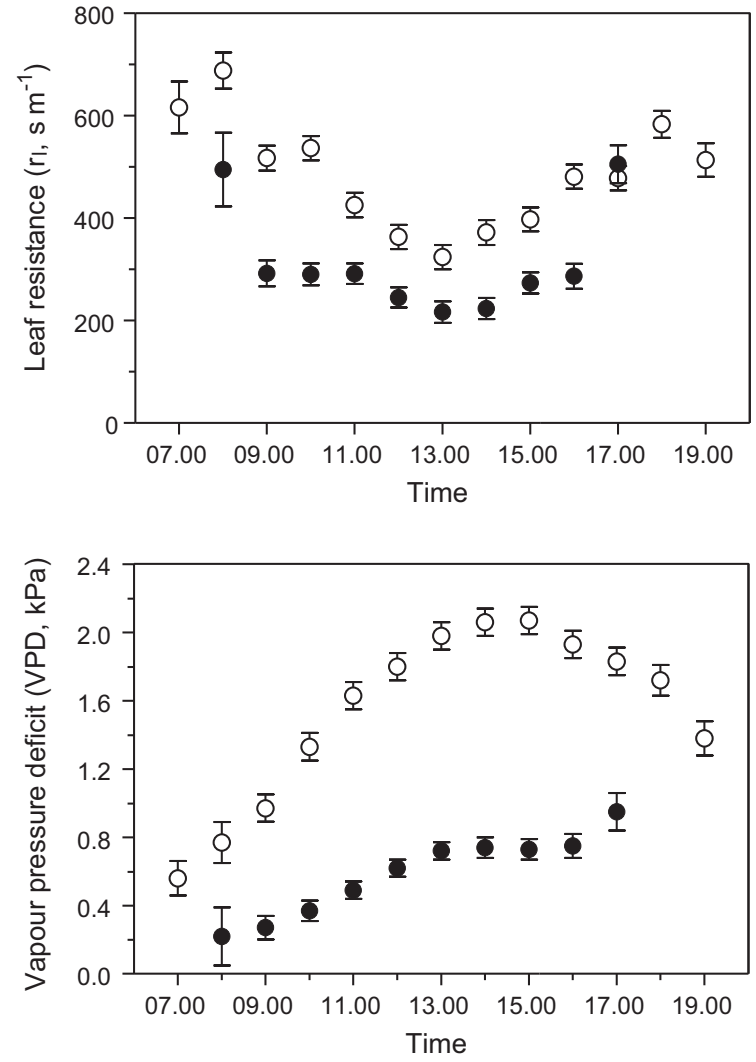

Fig. 3. Mean values of leaf stomatal resistance (as calculated with the PenmanMonteith equation, Eq. (1)) and vapour pressure deficit (VPD) in greenhouse gerbera grown in substrate culture in the autumn of 2004 (filled symbols) and in the spring of 2005 (empty symbols). Each point is the mean ( \pm SE) of 15-76 values.

\subsection{PM model}

The PM equation was run using a value of $0.10 \mathrm{~m} \mathrm{~s}^{-1}$ for $u$ and a difference of $1.0^{\circ} \mathrm{C}$ between $T_{\mathrm{a}}$ and $T_{\mathrm{l}}$. For each day of the study period in the spring of 2005, LAI was interpolated from the measurements on the basis of GDD using Eq. (10) (FW) or (11) (SW) Instead, a constant LAI was used for autumn crops: 0.98 in 2004 and 1.95 or 1.10 in 2005 (see previous section).

The calibration dataset $(n=593)$, which included the measurements taken in the autumn of $2004(n=257)$ and in the spring of 2005 ( $n=336)$, was used to develop empirical relations of $r_{1}$ against VPD, $I, I_{\mathrm{c}}$ and $T_{\mathrm{a}}$. Several functions were tested, including the multiplicative models reported by Jarvis (1976) and by Baille et al. (1994b). The latter authors modelled $r_{1}$ in a variety of greenhouse pot ornamentals as a function of $I$ and/or VPD. In most cases, the models explained more than $50 \%$ of the variability of $r_{1}$ with the exception of poinsettia; $R^{2}$ was much lower $(0.29)$ for this species.

Unfortunately, none of the tested equations acceptably described the relationship between $r_{1}$ and climatic variables (the values of $R^{2}$ were 0.30 or lower). Therefore, the PM model predicted $E_{\mathrm{d}}$ using a constant value of $r_{1}$. Other authors estimated daytime $E$ in greenhouse crops with the assumption of a constant $r_{1}\left(200 \mathrm{~s} \mathrm{~m}^{-1}\right.$; Aikman and Houter, 1990; Chalabi and Bailey, 1989).

The PM model was validated using an independent dataset $(n=781)$, which included the data collected in the autumn of 2005 . The validation was performed using separate values of $r_{1}$ for autumn $\left(282 \mathrm{~s} \mathrm{~m}^{-1}\right)$ and spring $\left(458 \mathrm{~s} \mathrm{~m}^{-1}\right)$, or their average $\left(370 \mathrm{~s} \mathrm{~m}^{-1}\right)$; these values were calculated using the calibration dataset.

The PM equation accurately predicted $E_{\mathrm{d}}$ in both seasons, with the slopes of the regression equations about to 1 , negligible intercepts and $R^{2}$ values close to 0.90 or higher (Table 3 ). Accurate 
Table 3

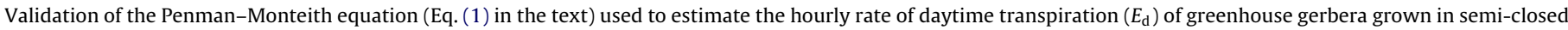

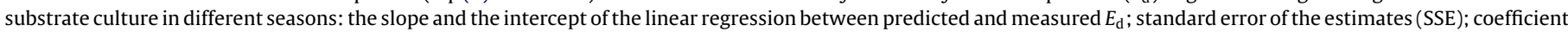
of determination $\left(R^{2}\right)$; mean absolute percentage error (MAPE); mean percentage error (PME).

\begin{tabular}{|c|c|c|c|c|c|c|c|}
\hline Season & Slope & Intercept $\left(\mathrm{kg} \mathrm{m}^{-2} \mathrm{~h}^{-1}\right)$ & $R^{2}$ & $\operatorname{SEE}\left(\mathrm{kg} \mathrm{m}^{-2} \mathrm{~h}^{-1}\right)$ & MAPE (\%) & $\operatorname{MPE}(\%)$ & $n$ \\
\hline Autumn & $0.872 \pm 0.009$ & $0.005 \pm 0.001$ & 0.953 & 0.012 & 16.4 & 2.4 & 457 \\
\hline Spring & $0.903 \pm 0.017$ & $0.013 \pm 0.003$ & 0.899 & 0.026 & 13.7 & -1.4 & 324 \\
\hline Autumn + spring & $0.985 \pm 0.010$ & $-0.001 \pm 0.001$ & 0.926 & 0.024 & 17.2 & 2.7 & 781 \\
\hline
\end{tabular}

Table 4

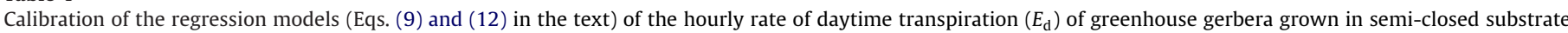
culture in different seasons: regression coefficients $(A$ and $B)$, coefficient of determination $\left(R^{2}\right)$ and number of observations $(n)$.

\begin{tabular}{|c|c|c|c|c|}
\hline Season & $A( \pm \mathrm{SE})$ & $B( \pm \mathrm{SE})\left(\mathrm{kg} \mathrm{m}^{-2} \mathrm{~h}^{-1} \mathrm{kPa}^{-1}\right)$ & $R^{2}$ & $n$ \\
\hline \multicolumn{5}{|l|}{ Eq. (9) } \\
\hline Autumn & $0.626 \pm 0.016$ & $0.024 \pm 0.001$ & 0.974 & 257 \\
\hline Spring & $0.553 \pm 0.020$ & $0.019 \pm 0.001$ & 0.974 & 336 \\
\hline Autumn + spring & $0.547 \pm 0.011$ & $0.019 \pm 0.001$ & 0.972 & 593 \\
\hline \multicolumn{5}{|l|}{ Eq. (12) } \\
\hline Autumn & $0.847 \pm 0.012$ & - & 0.947 & 257 \\
\hline Spring & $0.770 \pm 0.010$ & - & 0.942 & 336 \\
\hline Autumn + spring & $0.774 \pm 0.0080$ & - & 0.942 & 593 \\
\hline
\end{tabular}

estimates of $E_{\mathrm{d}}$ were also obtained using the average $r_{1}$ (Table 3 and Fig. 4).

\subsection{Regression models}

Eq. (9) was initially parameterized separating, for each growing season, the FW culture from the SW culture. Water salinity influenced the coefficient $A$ much less than the growing season, although this coefficient was higher for the FW culture than for the SW culture, both in autumn $(0.639 \pm 0.020$ against $0.609 \pm 0.027)$ and in spring $(0.559 \pm 0.019$ against $0.495 \pm 0.001)$. Both water salinity and growing season had no important effect on the coefficient $B$, which ranged from 0.019 to $0.024 \mathrm{~kg} \mathrm{~m}^{-2} \mathrm{~h}^{-1} \mathrm{kPa}^{-1}$ (Table 4).

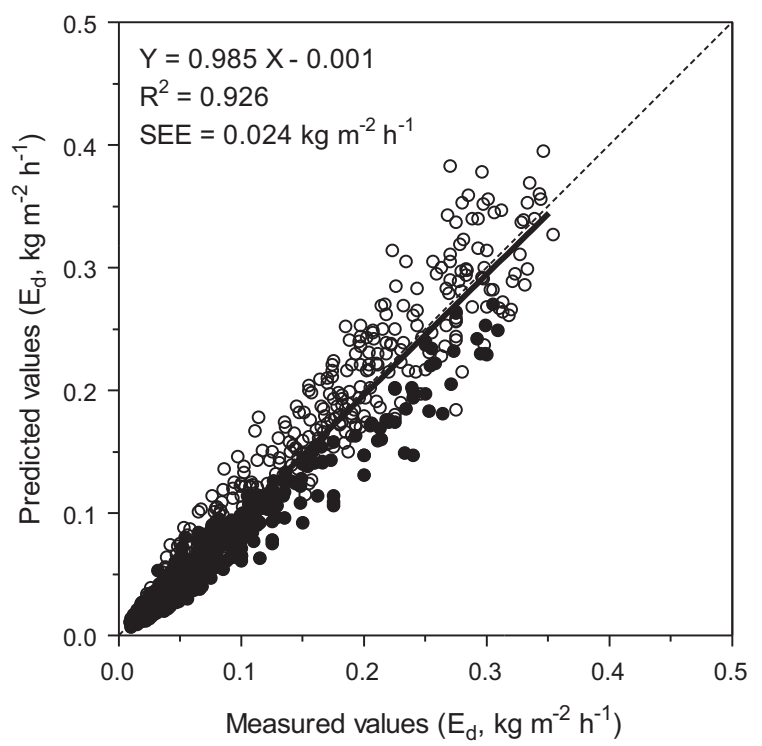

Fig. 4. Relationship between predicted and measured values of daytime transpiration $\left(E_{\mathrm{d}}\right)$ in greenhouse gerbera grown in substrate culture in different seasons (autumn, filled symbols; spring, empty symbols). Transpiration was predicted using the Penman-Monteith equation (Eq. (1) in the text) and assuming a constant value of leaf stomatal resistance $\left(370 \mathrm{~s} \mathrm{~m}^{-1}\right)$. Solid line represents the linear regression (the equation is reported inside the graph) between predicted and measured $E_{\mathrm{d}}$ while dotted line is the $1: 1$ relationship. The slope and the intercept of the linear regression were not significantly different from 1 and 0 , respectively.
When data collected in FW and SW crops were pooled in each season, the coefficients $A$ and $B$ were, respectively: 0.626 and $0.024 \mathrm{~kg} \mathrm{~m}^{-2} \mathrm{~h}^{-1} \mathrm{kPa}^{-1}$ in autumn; 0.553 and $0.019 \mathrm{~kg} \mathrm{~m}^{-2} \mathrm{~h}^{-1} \mathrm{kPa}^{-1}$ in spring (Table 4). Higher $A$ in autumn is consistent with lower $r_{1}$ in this season compared to spring (Fig. 3, top). Using the validation datasets, we found a good agreement between predicted and measured $E_{\mathrm{d}}$ (Table 5), although the models tended to overestimate $E_{\mathrm{d}}$ (MPEs were negative) with MAPE ranging from $15.4 \%$ to $17.7 \%$.

A joint regression analysis of data from different seasons produced the following results (Table 4 ): $A$ was 0.547 and $B$ was $0.019 \mathrm{~kg} \mathrm{~m}^{-2} \mathrm{~h}^{-1} \mathrm{kPa}^{-1}$. With these coefficients, Eq. (9) predicted accurately measured $E_{\mathrm{d}}$; the slope was close to $1(0.949)$ and the intercept (0.002 $\mathrm{kg} \mathrm{m}^{-2} \mathrm{~h}^{-1}$ ) was negligible (Table 5 and Fig. 5).

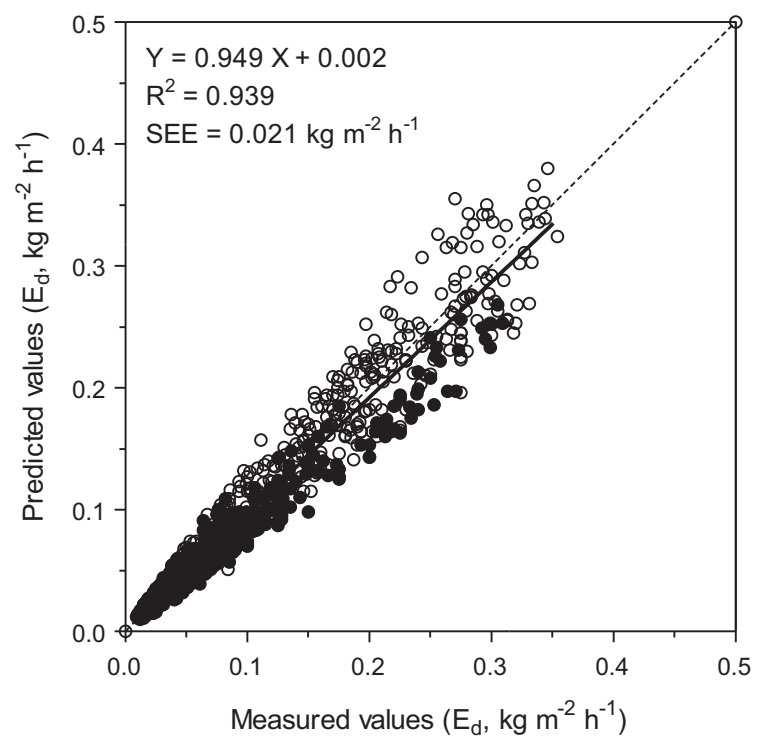

Fig. 5. Relationship between predicted and measured values of daytime transpiration $\left(E_{\mathrm{d}}\right)$ in greenhouse gerbera grown in substrate culture in different seasons (autumn, filled symbols; spring, empty symbols). Transpiration was predicted using an empirical function (Eq. (9) in the text) of Ed against intercepted radiation and vapour pressure deficit. Solid line represents the linear regression (the equation is reported inside the graph) between predicted and measured $E_{\mathrm{d}}$ while dotted line is the 1:1 relationship. The intercept of the linear regression was not significantly different from 0. 
Table 5

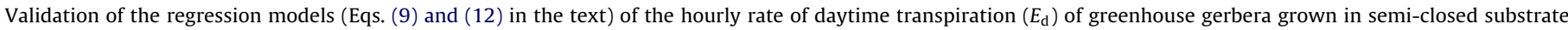

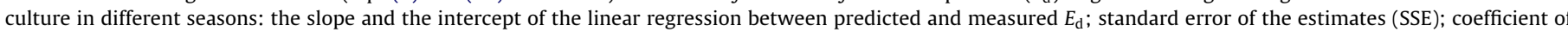
determination $\left(R^{2}\right)$; mean absolute percentage error (MAPE); mean percentage error (PME).

\begin{tabular}{|c|c|c|c|c|c|c|c|}
\hline Season & Slope & Intercept $\left(\mathrm{kg} \mathrm{m}^{-2} \mathrm{~h}^{-1}\right)$ & $R^{2}$ & $\operatorname{SEE}\left(\mathrm{kg} \mathrm{m}^{-2} \mathrm{~h}^{-1}\right)$ & MAPE (\%) & MPE (\%) & $n$ \\
\hline \multicolumn{8}{|l|}{ Eq. (9) } \\
\hline Autumn & $0.950 \pm 0.009$ & $0.007 \pm 0.001$ & 0.960 & 0.012 & 17.7 & -10.9 & 457 \\
\hline Spring & $0.945 \pm 0.016$ & $0.014 \pm 0.003$ & 0.910 & 0.026 & 14.6 & -6.0 & 324 \\
\hline Autumn + spring & $0.949 \pm 0.009$ & $0.002 \pm 0.001$ & 0.939 & 0.021 & 15.4 & 1.1 & 781 \\
\hline \multicolumn{8}{|l|}{ Eq. (12) } \\
\hline Autumn & $0.944 \pm 0.015$ & $0.007 \pm 0.001$ & 0.900 & 0.020 & 24.3 & -10.8 & 457 \\
\hline Spring & $0.951 \pm 0.027$ & $0.003 \pm 0.005$ & 0.793 & 0.043 & 22.6 & 2.7 & 324 \\
\hline Autumn + spring & $0.939 \pm 0.013$ & $0.0031 \pm 0.002$ & 0.875 & 0.031 & 22.0 & 0.2 & 781 \\
\hline
\end{tabular}

A linear regression (forced through the origin) of $E_{\mathrm{d}}$ against $I_{\mathrm{C}}$ was also evaluated:

$E_{\mathrm{d}}=A \cdot \frac{I_{\mathrm{c}}}{\lambda}$

The calibration yielded a slope of 0.847 in autumn and 0.770 in spring; the slope was 0.774 when data for autumn and spring were pooled (Table 4 ). Therefore, gerbera plants converted around $80 \%$ of the incident energy into latent heat in agreement with previous findings in greenhouse crops (e.g. Baille et al., 1994a; Carmassi et al., 2007a; Teitel et al., 2008). Eq. (12) predicted satisfactorily $E_{\mathrm{d}}$, although model accuracy was lower compared to the PM model and Eq. (9), as indicated by the differences in $R^{2}$, SEE and MAPE (Tables 3 and 5).

In substrate cultures of tomato in unheated greenhouse, Massa et al. (2011) found that a linear regression with $I_{\mathrm{c}}$ explained $81-93 \%$ of the variation in daily $W$, which was dominated by $E$ (it corresponded to more than 93\% of $W$ ). According to Stanghellini (1987), in most climates the $E$ of greenhouse crops can be better estimated as a function of measured radiation than of VPD.

A simple model that predicts $E$ as a function of radiation can be easily applied in low-technology greenhouses that may have only a simple solarimeter or gather meteorological data from local weather station. In modern greenhouses, indoor climate is automatically monitored and $E$ models responding to changes of both radiation and air humidity can be easily implemented in algorithms for irrigation and climate control.

A linear regression was also fitted to $E_{\mathrm{n}}$ using the whole calibration dataset $(n=338$ ), with VPD ranging from approximately 0.1 to $1.0 \mathrm{kPa}$ :

$E_{\mathrm{n}}=B \cdot \mathrm{LAI} \cdot \mathrm{VPD}$

The calibration yielded a slope of $0.015 \mathrm{~kg} \mathrm{~m}^{-2} \mathrm{~h}^{-1} \mathrm{kPa}^{-1}$ $\left(R^{2}=0.876 ; n=338\right)$. There was a good correspondence between predicted and measured $E_{\mathrm{n}}\left(R^{2}=0.918 ; n=569\right)$ with a slope close to 1 (0.929) and a negligible intercept $\left(0.0005 \mathrm{~kg} \mathrm{~m}^{-2} \mathrm{~h}^{-1}\right)$; SEE, MPE and MAPE were $0.002 \mathrm{~kg} \mathrm{~m}^{-2} \mathrm{~h}^{-1},-0.1 \%$ and $13.9 \%$, respectively

The same linear regression (with $B=0.026 \mathrm{~kg} \mathrm{~m}^{-2} \mathrm{~h}^{-1} \mathrm{kPa}^{-1}$ ) accounted for $80 \%$ of measured $E_{\mathrm{n}}$ in greenhouse cucumber (Medrano et al., 2005).

\subsection{Radiative and aerodynamic components of transpiration}

The first term on the right-hand side of Eq. (1) is referred to as the "radiation term" while the second as the "aerodynamic term" (Seginer, 2002); they correspond to the coefficients $A$ and $B$ of Eq. (9) (Baille et al., 1994a; Seginer, 2002).

Baille et al. (1994a) reported that the contribution of the two PM terms was similar in some ornamental species (e.g. begonia, cyclamen and gloxinia) grown under greenhouse in a Mediterranean climate while the radiation term was the main component in other species (e.g. gardenia, impatiens, pelargonium and schefflera). In our work, the radiative component of gerbera $E_{\mathrm{d}}$ (calculated using Eq. (9)) averaged $76 \%$ in autumn and $66 \%$ in spring.

From a practical point of view, the estimation of radiative and aerodynamic components can suggest the efficacy of climate control devices, such as shading net and fog system, for $E$ reduction, which may be necessary during plant recovery from root disease or salinity stress, for instance. For crops with high values of $A$ (like gerbera, for instance) shading screen will be much more effective in reducing $E_{\mathrm{d}}$ than fog system.

According to Jones and Tardieu (1999), the aerodynamic term may be not necessary to predict $E$ in greenhouse crops, since greenhouses are generally scantily ventilated, unlike the open field, and thus 'decoupled' from the atmospheric air. In a 'decoupled' greenhouse, VPD is positively correlated to $I$, as it was found in our work, and there is large uncertainty of partitioning between the radiative and aerodynamic components of $E$. On the other hand, $I$ and VPD could become uncorrelated under greenhouse conditions (Bakker, 1991) due to strong climate conditioning (Baille et al., 1994a).

The values of the coefficients $A$ and $B$ determined for gerbera in our work were within those reported for other greenhouse crops in Mediterranean regions (Table 6). The pairs $(A, B)$ reported in Table 6 and those determined for gerbera in our study using the complete calibration dataset (Table 4) are shown in Fig. 6; the pair with zero $B$ (Eq. (12)) was also included. The divergence among the crops could be ascribed to differences in plant habit, stomatal resistance and growing conditions. In spite of scatter, there is an apparent negative correlation between $A$ and $B$, with a significant $R^{2}(0.366)$.

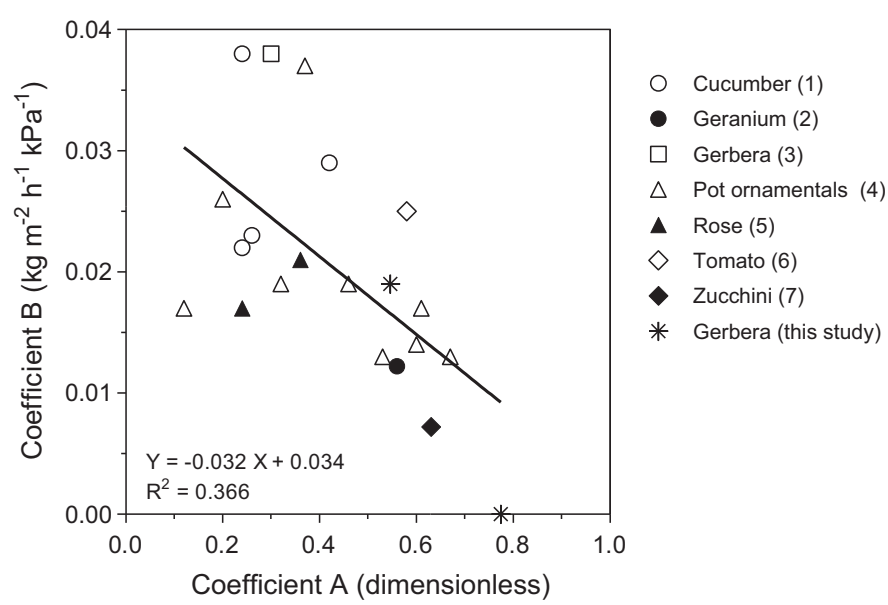

Fig. 6. Relationship between the values of $A$ and $B$ coefficients of Eq. (9) in the text as computed for gerbera in this study or reported in the literature for other greenhouse crops. Solid line represents the linear regression (the equation is reported inside the graph). References: (1) cucumber: Medrano et al. (2005); (2) geranium: Montero et al. (2001); (3) gerbera: Marfà et al. (2000); (4) pot ornamentals: Baille et al. (1994a,b); (5) rose: Kittas et al. (1999) and Gonzalez-Real (1994); (6) tomato: Medrano et al. (2004); (7) zucchini: Rouphael and Colla (2004). 
Table 6

Values of coefficients $A$ and $B$ of Eq. (9) in the text for some greenhouse crops.

\begin{tabular}{|c|c|c|c|c|}
\hline Crop & Growing conditions ${ }^{\mathrm{a}}$ & $A$ & $B\left(\mathrm{~kg} \mathrm{~m}^{-2} \mathrm{~h}^{-1} \mathrm{kPa}^{-1}\right)$ & Reference \\
\hline Begonia & \multirow{9}{*}{$\begin{array}{l}\text { Angers, France; spring, summer or autumn; } \\
10-20 \text { plants } \mathrm{m}^{-2} \text {; peat-rockwool (pot plants). }\end{array}$} & 0.20 & 0.026 & \multirow{9}{*}{ Baille et al. (1994a) } \\
\hline Cyclamen & & 0.32 & 0.019 & \\
\hline Gardenia & & 0.46 & 0.019 & \\
\hline Gardenia & & 0.53 & 0.013 & \\
\hline Hibiscus & & 0.37 & 0.037 & \\
\hline Impatiens & & 0.67 & 0.013 & \\
\hline Pelargonium & & 0.61 & 0.017 & \\
\hline Poinsettia & & 0.12 & 0.017 & \\
\hline Schefflera & & 0.60 & 0.014 & \\
\hline Cucumber & Almeria, Spain; autumn (2 plants $\mathrm{m}^{-2}$ ) and spring ( 1.33 plants $\mathrm{m}^{-2}$ ); perlite & $0.24-0.42$ & $0.022-0.038$ & Medrano et al. (2005) \\
\hline Geranium & Barcelona, Spain; May-July; pot plants (unknown crop density and substrate) & 0.56 & $0.012^{\mathrm{b}}$ & Montero et al. (2001) \\
\hline Gerbera & Barcelona, Spain; July-March; 5.7 plants $\mathrm{m}^{-2}$; perlite & 0.30 & $0.038^{\mathrm{b}}$ & Marfà et al. (2000) \\
\hline Rose & Volos, Greece; winter; 6 plants $\mathrm{m}^{-2}$; perlite & 0.24 & 0.017 & Kittas et al. (1999) \\
\hline Rose & Valencia, Spain; summer; 7 plants $\mathrm{m}^{-2}$; rockwool & 0.36 & 0.021 & Gonzalez-Real (1994) \\
\hline Tomato & Almeria, Spain; autumn and spring; 7 plants $\mathrm{m}^{-2}$; perlite bag & 0.58 & 0.025 & Medrano et al. (2004) \\
\hline Zucchini & Viterbo, Italy; autumn and spring; 2.1 plants $\mathrm{m}^{-2}$; pumice & 0.63 & $0.007^{\mathrm{b}}$ & Rouphael and Colla (2004) \\
\hline
\end{tabular}

${ }^{\text {a }}$ Location, season, crop density and type of substrate.

b The original data were converted to $B\left(\mathrm{~kg} \mathrm{~m}^{-2} \mathrm{~h}^{-1} \mathrm{kPa}^{-1}\right)$ of this paper.

The relationship between $A$ and $B$ and its significance for greenhouse ventilation design have been analyzed by Seginer (2002). According to this author, two reasons may account for negative correlation between $A$ and $B$ :

(i) a difference in greenhouse (reference) temperature. As $\Delta$ increases with temperature, the first and the second term of Eq. (1) are functions of temperature, if $r_{\mathrm{c}}$ and $r_{\mathrm{a}}$ do not change; however, $A$ augments with temperature while $B$ decreases when the temperature increases.

(ii) The decoupling of greenhouse from the atmospheric air as a result of poor ventilation, as previously discussed.

Several authors calculated the Jarvis and McNaughton's (1986) decoupling coefficient $\Omega$ (Eq. (8)) to analyze the influence of physical and physiological factors on canopy $E$ both in natural vegetation (e.g. Magnani et al., 1998) and in crop plantations in open field or under cover (e.g. Dayan et al., 2000; Nicolàs et al., 2008). The coefficient $\Omega$ describes the degree to which $E$ is controlled by radiation rather than by stomata (Jarvis and McNaughton, 1986; Polhamus et al., 2013). It ranges from 0 (strong influence of stomata on $E$, because VPD at canopy surface is coupled to air VPD) to 1 (decoupled canopy; $E$ is controlled by radiation and independent on stomata behaviour).

Under greenhouse, the degree of coupling between the crop and the ambient air depends on ventilation (Boulard, 1996). Our experiments were conducted in a greenhouse that was poorly ventilated (discontinuous measurements of u never exceeded $0.2 \mathrm{~m} \mathrm{~s}^{-1}$ ) due to its urban location and, more notably, to the presence of insect screens and, in late spring and summer, shading net. The coefficient $\Omega$ averaged $0.69 \pm 0.11$ in autumn and $0.65 \pm 0.11$ in spring. Gerbera vegetation is short and compact and this seemingly contributed to canopy decoupling (Jones and Tardieu, 1999).

Therefore, in our experiment gerbera crop was poorly coupled to the ambient air and this explains why $E_{\mathrm{d}}$ was accurately predicted either using the PM equation (Table 3 ) with the assumption of a constant $r_{1}$ (this assumption is also implicit in the regression models) or as a function of the sole radiation (Eq. (12)), although the accuracy of $E_{\mathrm{d}}$ predictions increased when VPD was also considered (Eq. (9); Table 5).

\section{Conclusions}

In greenhouse gerbera grown in substrate in different seasons, moderate $\mathrm{NaCl}$ salinity of irrigation water reduced plant growth, flower production and $E$ in spring while no significant effects on all measured quantities were observed in autumn.

$\mathrm{NaCl}$ salinity affected $E$ through an inhibition of leaf area development and not through stomatal closure, as $r_{1}$ did not differ significantly in salinized and non-salinized plants both in autumn and in spring. This avoided the necessity of a different calibration of $E$ models for the crop irrigated with FW or SW. However, it required the use of different sub-models of leaf area development depending on water salinity.

The PM model was run using a constant value of $r_{1}$. Both the PM formula and the regression equations predicted satisfactorily $E_{\mathrm{d}}$ in both seasons. Our findings are consistent with the concept of greenhouse crop decoupling from the atmosphere.

The models could be easily implemented for irrigation and climate control. All the equations require LAI, which can be estimated either from recurrent, non-destructive measurements of leaf dimensions or as a function of crop thermal time.

\section{Acknowledgements}

This work was supported by Ministry of University and Research (MIUR-PRIN 2004-2005) and by the European Commission, Directorate General for Research (7th Framework RTD Programme, Project EUPHOROS, 2008-2012). We are grateful to two anonymous referees for their constructive comments to the manuscript.

\section{References}

Aikman, D.P., Houter, G., 1990. Influence of radiation and humidity on transpiration - implications for calcium levels in tomato leaves. J. Hortic. Sci. 65, 245-253.

Allen, R.G., Pereira, L.S., Raes, D., Smith, M., 1998. Crop evapotranspiration: guidelines for computing crop water requirements. Irrigation Drainage Paper 56, FAO, Rome. Available at: http://www.fao.org/docrep/X0490E/x0490e00.htm (accessed 31.01.13)

An, P., Inanaga, S., Lux, A., Li, X.J., Ali, M.E.K., Matsui, T., Sugimoto, Y., 2002. Effects of salinity and relative humidity on two melon cultivars differing in salt tolerance. Biol. Plantarum 45, 409-441.

Baas, R., Nijssen, H.M.C., Van Den Berg, T.J.M., Warmenhoven, M.G., 1995. Yield and quality of carnation (Dianthus caryophyllus L.) and gerbera (Gerbera jamesonii L.) in a closed nutrient system as affected by sodium chloride. Sci. Hortic. 61, 273-284.

Bailey, B.J., Montero, J.I., Blel, C., Wilkinson, D.J., Anton, A., Jolhet, O., 1993. Transpiration of Ficus benjamina: comparison of measurements with predictions of the Penman-Monteith model and a simplified version. Agric. Forest Meteorol. 65, 229-243.

Baille, K., Baille, A., Delmon, D., 1995. Microclimate and transpiration of greenhouse rose crops. Agric. Forest Meteorol. 71, 83-97.

Baille, M., Baille, A., Laury, J.C., 1994a. A simplified model for predicting evapotranspiration rate of nine ornamental species vs climate factors and leaf area. Sci. Hortic. 59, 217-232. 
Baille, M., Baille, A., Laury, J.C., 1994b. Canopy surface resistances to water vapour transfer for nine greenhouse pot plant crops. Sci. Hortic. 57, 143-155.

Bakker, J.C., 1991. Leaf conductance of four glasshouse vegetable crops as affected by air humidity. Agric. Forest Meteorol. 55, 23-36.

Boulard, T., 1996. Caracterisation et modélisation du climat des serres. Application à la climatisation estivale. PhD Thesis. ENSA Montpellier, France. 121 pp.

Boulard, T., Baille, A., Le Gall, F., 1991. Etude de différentes méthodes de refroidissement sur le climat et la transpiration de tomates de serre. Agronomie 11, 543-553.

Bunce, J.A., 1996. Growth at elevated carbon dioxide concentration reduces hydraulic conductance in alfalfa and soybean. Global Change Biol. 2, 155-158.

Carmassi, G., Incrocci, L., Maggini, R., Malorgio, F., Tognoni, F., Pardossi, A., 2007a. An aggregated model for water requirements of greenhouse tomato grown in closed rockwool culture with saline water. Agric. Water Manage. 88, 73-82.

Carmassi, G., Incrocci, L., Incrocci, G., Pardossi, A., 2007b. Non-destructive estimation of leaf area in (Solanum lycopersicum L.) and gerbera (Gerbera jamesonii H. Bolus). Agric. Mediterr. 137, 172-176.

Chalabi, Z.S., Bailey, B.J., 1989. Simulation of the energy balance in a greenhouse. Divisional note 1516/AFRC, Institute of Engineering Research.

Dayan, E., Fuchs, M., Plaut, Z., Presnov, E., Grava, A., Matan, E., Solphoy, A., Mugira, U., Pines, N., 2000. Transpiration of roses in greenhouses. Acta Hortic. 554, 239-249.

De Kreij, C., van Os, P.C., 1989. Production and quality of gerbera in rockwool as affected by electrical conductivity of the nutrient solution. In: Proc. 7 th Int. Cong. Soilless Culture, pp. 225-264.

Elings, A., Voogt, W., 2007. Management of greenhouse crop transpiration: the way forward. Acta Hortic. 801, 1221-1228.

Gonzalez-Real, M.M., 1994. Estudio y modelizacion de intercambios gaseosos en el cultivo de rosas bajo invernadero. Universidad Politecnica de Valencia, Valencia.

Gröber, H., Erk, S., 1961. Fundamentals of heat transfer, $3^{\text {d }}$ ed. McGraw-Hill, New York.

Issa, M., Ouzounidou, G., Maloupa, H., Constantinidou, H.I.A., 2001. Seasonal and diurnal photosynthetic responses of two gerbera cultivars to different substrates and heating systems. Sci. Hortic. 88, 215-234.

Jarvis, P.G., 1976. Interpretation of variations in leaf water potential and stomatal conductance found in canopies in field. Philos. Trans. Roy. Soc. B 273, 593-610.

Jarvis, P.G., McNaughton, K.G., 1986. Stomatal control of transpiration: scaling up from leaf to region. Adv. Ecol. Res. 15, 3-50.

Jones, H.G., Tardieu, F., 1999. Modelling water relations of horticultural crops. A review. Sci. Hortic. 74, 21-46.

Kirkham, M.B., 2011. Elevated atmospheric carbon dioxide: transpiration and evapotranspiration. In: Kirkham, M.B. (Ed.), Elevated Carbon Dioxide: Impacts on Soil and Plant Water Relations. CRC Press, Boca Raton, FL, pp. 197-224.

Kittas, C., Katsoulas, N., Baille, A., 1999. Transpiration and canopy resistance of greenhouse soilless roses: measurements and modelling. Acta Hortic. 507, 61-68.

Li, Y., Stanghellini, C., Challa, H., 2001. Effect of electrical conductivity and transpiration on production of greenhouse tomato (Lycopersicon esculentum L.). Sci. Hortic. 88, 11-29.

Magnani, F., Leonardi, S., Tognetti, R., Grace, J., Borghetti, M., 1998. Modelling the surface conductance of a broad-leaf canopy: effects of partial decoupling from the atmosphere. Plant Cell Environ. 21, 867-879.

Marfà, O., Biel, C., Blanch, F., Montero, J.I., 2000. Water consumption of a closed soilless culture of gerbera: usefulness of model to estimate evapotranspiration. Acta Hortic. 534, 147-153.

Massa, D., Incrocci, L., Maggini, R., Bibbiani, C., Carmassi, G., Malorgio, F., Pardossi, A., 2011. Simulation of crop water and mineral relations in greenhouse soilless culture. Environ. Modell. Softw. 26, 711-722.

Massa, D., Incrocci, L., Maggini, R., Carmassi, G., Campiotti, C.A., Pardossi, A., 2010. Strategies to decrease water drainage and nitrate emission from soilless cultures of greenhouse tomato. Agric. Water Manage. 97, 971-980.

McAdams, W.H., 1954. Heat transmission, $3^{\text {d }}$ ed. McGraw-Hill, New York.

Medrano, E., Lorenzo, P., Sánchez-Guerrero, M.C., García, M.L., Caparrós, I., Giménez, M., 2004. Influence of an external greenhouse mobile shading on tomato crop transpiration. Acta Hortic. 659, 195-199.
Medrano, E., Lorenzo, P., Sanchez-Guerrero, M.C., Montero, J.I., 2005. Evaluation and modelling of greenhouse cucumber-crop transpiration under high and low radiation conditions. Sci. Hortic. 105, 163-175.

Mohd, R.I., Davies, W.J., Mohamad, H.A., 2002. Leaf growth and stomatal sensitivity to ABA in droughted pepper plants. Sci. Hortic. 96, 313-327.

Montero, J.I., Antón, A., Muñoz, P., Lorenzo, P., 2001. Transpiration from geranium grown under high temperatures and low humidities in greenhouses. Agric. Forest Meteorol. 107, 323-332.

Nicolàs, E., Barradas, V.L., Ortuño, M.F., Navarro, A., Torrecillas, A.A., Alarcón, J.J., 2008 Environmental and stomatal control of transpiration, canopy conductance and decoupling coefficient in young lemon trees under shading net. Environ. Exp. Bot. 63, 200-206.

Nobel, P.S., Long, S.P., 1985. Canopy structure and light interception techniques In: Coombs, J., Hall, D.O., Long, S.P., Scurlock, J.M.O. (Eds.), Bioproductivity and Photosynthesis. Pergamon Press, Oxford, pp. 41-49.

Pardossi, A., Incrocci, L., 2011. Traditional and new approaches to irrigation scheduling in vegetable crops. HortTechnology 21, 309-313.

Pardossi, A., Tognoni, F., Incrocci, L., 2004. Mediterranean greenhouse technology. Chronica Hortic. 44, 28-34

Plaut, Z., Meinzer, F.C., Federman, E., 2000. Leaf development, transpiration and ion uptake and distribution in sugarcane cultivars grown under salinity. Plant Soil 218, 59-69.

Polhamus, A., Joshua, B., Fisher, J.B., Kevin, P., Tu, K.P., 2013. What controls the error structure in evapotranspiration models? Agric. Forest Meteorol. 169, 12-24.

Pollet, S., Bleyaert, P., Lemeur, R., 2000. Application of the Penman-Monteith model to calculate the evapotranspiration of head lettuce (Lactuca sativa L. var. capitata) in glasshouse conditions. Acta Hortic. 519, 151-162.

Rouphael, Y., Colla, G., 2004. Modelling the transpiration of a greenhouse zucchini crop grown under a Mediterranean climate using the Penman-Monteith equation and its simplified version. Aust. J. Agric. Res. 55, 931-937.

Saab, I.N., Sharp, R.E., 1989. Non-hydraulic signals from maize roots in drying soil: inhibition of leaf elongation but not stomatal conductance. Planta 179, 466-474.

Savvas, D., Chatzieustratiou, E., Pervolaraki, G., Gizas, G., Sigrimis, N., 2008. Modelling $\mathrm{Na}$ and $\mathrm{Cl}$ concentrations in the recycling nutrient solution of a closedcycle pepper cultivation. Biosyst. Eng. 99, 282-291.

Seginer, I., 2002. The Penman-Monteith evapotranspiration equation as an element in greenhouse ventilation design. Biosyst. Eng. 82, 423-439.

Sonneveld, C., Baas, R., Nijssen, H.M.C., de Hoog, J., 1999. Salt tolerance of flower crops grown in soilless culture. J. Plant Nutr. 22, 1033-1048.

Stanghellini, C., 1987. Transpiration of greenhouse crops. An aid to climate management. PhD Thesis. Wageningen Agricultural University, The Netherlands, 150 pp.

Stanghellini, C., Pardossi, A., Sigrimis, N., 2007. What limits the application of wastewater and/or closed cycle in horticulture? Acta Hortic. 747 323-330.

Teitel, M., Liran, O., Tanny, J., Barak, B., 2008. Wind driven ventilation of a monospan greenhouse with a rose crop and continuous screened side vents and its effect on flow patterns and microclimate. Biosyst. Eng. 101, 111-122.

Thompson, R.B., Martínez-Gaitan, C., Gallardo, M., Giménez, C., Fernández, M.D. 2007. Identification of irrigation and $\mathrm{N}$ management practices that contribute to nitrate leaching loss from an intensive vegetable production system by use of a comprehensive survey. Agric. Water Manage. 89, 261-274.

Thornley, J.H.M., Johnson, I.R., 1990. Plant and Crop Modelling. A Mathematical Approach to Plant and Crop Physiology. Clarendon Press, Oxford.

Tsirogiannis, I., Katsoulas, N., Kittas, C., 2010. Effect of irrigation scheduling on gerbera flower yield and quality. HortScience 45, 265-270.

Vidalie, H., 2007. Varietal richness and technology for gerbera. PHM Rev. Hortic. 497, 33-41.

Volkmar, K.M., Hu, Y., Steppuhn, H., 1998. Réponse physiologique des plantes à la salinité: Mise au point bibliographique. Can. J. Plant Sci. 78, 19-27.

Vox, G., Teitel, M., Pardossi, A., Minuto, A., Tinivella, F., Schettini, E., 2010. Sustainable greenhouse systems. In: Salazar, A., Rios, I. (Eds.), Agriculture: Technology, Planning and Management. Nova Sci Publishers, New York, pp. 1-79. 